Article

\title{
Calcium Oxalates in Lichens on Surface of Apatite-Nepheline Ore (Kola Peninsula, Russia)
}

\author{
Olga V. Frank-Kamenetskaya ${ }^{1, *}$ (D), Gregory Yu. Ivanyuk ${ }^{2} \mathbb{B}$, Marina S. Zelenskaya ${ }^{3}$, \\ Alina R. Izatulina ${ }^{1}\left(\mathbb{D}\right.$, Andrey O. Kalashnikov ${ }^{2}$, Dmitry Yu. Vlasov ${ }^{3}$ and \\ Evgeniya I. Polyanskaya ${ }^{1}$ \\ 1 Crystallography Department, Institute of Earth Sciences, St. Petersburg State University, University emb. 7/9, \\ 199034 St. Petersburg, Russia; alina.izatulina@mail.ru (A.R.I.); polianskaya2017@mail.ru (E.I.P.) \\ 2 Kola Science Centre, Russian Academy of Sciences, Fersmana Street 14, 184209 Apatity, Russia; \\ g.ivanyuk@gmail.com (G.Y.I.); kalashnikov@geoksc.apatity.ru (A.O.K.) \\ 3 Botany Department, St. Petersburg State University, University emb. 7/9, 199034 St. Petersburg, Russia; \\ marsz@yandex.ru (M.S.Z.); dmitry.vlasov@mail.ru (D.Y.V.) \\ * Correspondence: ofrank-kam@mail.ru; Tel.: +7-921-331-68-02
}

Received: 13 September 2019; Accepted: 23 October 2019; Published: 25 October 2019

check for updates

\begin{abstract}
The present work contributes to the essential questions on calcium oxalate formation under the influence of lithobiont community organisms. We have discovered calcium oxalates in lichen thalli on surfaces of apatite-nepheline rocks of southeastern and southwestern titanite-apatite ore fields of the Khibiny peralkaline massif (Kola Peninsula, NW Russia) for the first time; investigated biofilm calcium oxalates with different methods (X-ray powder diffraction, scanning electron microscopy, and EDX analysis) and discussed morphogenetic patterns of its formation using results of model experiments. The influence of inorganic and organic components of the crystallization medium on the phase composition and morphology of oxalates has been analyzed. It was shown that, among the complex of factors controlling the patterns of biogenic oxalate formation, one of the main roles belongs to the metabolic activity of the lithobiont community organisms, which differs significantly from the activity of its individuals.
\end{abstract}

Keywords: microbial biomineralization; calcium oxalates; lichens; apatite-nepheline ore; X-ray powder diffraction; scanning electron microscopy; EDX analysis

\section{Introduction}

Crystalline salts of oxalic acid, in particular calcium oxalate monohydrate (whewellite, $\left.\mathrm{Ca}\left(\mathrm{C}_{2} \mathrm{O}_{4}\right) \cdot \mathrm{H}_{2} \mathrm{O}\right)$ and calcium oxalate dihydrate (weddellite, $\left.\mathrm{Ca}\left(\mathrm{C}_{2} \mathrm{O}_{4}\right) \cdot(2.5-\mathrm{x}) \mathrm{H}_{2} \mathrm{O}\right)$, are the most common mineral phases forming in the presence of lichens and microscopic fungi. These minerals are often found in thalli of crustose and foliose lichens growing on the surface of carbonate rocks, such as marble, limestone, and dolomite (Table 1). Moreover, they were found on the surface of calcium-containing silicate rocks: granite, serpentinite, gabbro, etc. (Table 1). It is known according to the results of model experiments that crystallization of oxalates on the surface of minerals in rocks can occur under the influence of microscopic fungi metabolites involved in the formation of biofilms along with lichens [1-5].

Lichens living on carbonate or silicate rocks, in which calcium oxalates were found, can be both epilithic and endolithic. According to the structure of the thallus, they are mainly crustose, but foliose species are also found. Usually, authors make a conclusion about the release of oxalic acid by the mycobiont of lichens according to the presence of oxalates in their thalli [6-8]. Therefore, the determination of the lichen species in which whewellite and/or weddellite are found is an important 
task, and its solution in the future could allow for the identification of typomorphic signs of biofouling associated with the oxalate formation.

Table 1. Lichen species on the surface of various rocks in which calcium oxalates (whewellite, weddellite) were found (literature data).

\begin{tabular}{|c|c|c|}
\hline Bedrock & Lichen Types & References \\
\hline $\begin{array}{c}\text { Carbonate rocks: } \\
\text { limestone (caliche, calcarenite), } \\
\text { marble, dolostone (dolomite), } \\
\text { calcite enriched schist-greywacke }\end{array}$ & $\begin{array}{c}\text { Circinaria calcarea (Aspicilia calcarea), } \\
\text { Circinaria hoffmanniana (A. Hoffmanniana), } \\
\text { Circinaria contorta (A. Hoffmannii), } \\
\text { Lobothallia radiosa (A radiosa) } \\
\text { Bagliettoa parmigera } \\
\text { B. parmigerella, } \\
\text { Botryolepraria lesdanii } \\
\text { Diplotomma epipolium (Buellia epipolia) } \\
\text { Variospora aurantia (Caloplaca aurantia, C. } \\
\text { callopisma), } \\
\text { Variospora dolomiticola (C. dolomiticola), } \\
\text { Variospora flavescens (C. flavescens, C. heppiana) } \\
\text { Caloplaca lactea, C. ochracea, } \\
\text { Squamulea subsoluta (C. subsoluta) } \\
\text { Caloplaca teicholyta } \\
\text { Candelariella medians } \\
\text { Clauzadea immerse } \\
\text { Diplocia canescens } \\
\text { Diploschistes diacapsis, } \\
\text { Xalocoa ocellata (D. ocellatus) } \\
\text { Myriolecis pruinosa (Lecanora pruinosa) } \\
\text { Circinaria calcarea (L. calcarea) } \\
\text { Myriolecis crenulata (L. crenulata) } \\
\text { Protoparmeliopsis muralis (L. muralis) } \\
\text { L. pseudistera } \\
\text { Peltula euploca } \\
\text { Physcia adscendens, Ph. Caesia } \\
\text { Psora testacea (Protoblastenia testacea) } \\
\text { P. incrustans, } \\
\text { P. rupestris } \\
\text { Rhizocarpon umbilicatum } \\
\text { Sarcogyne regularis, S. pruinosa } \\
\text { Squamarina oleosa } \\
\text { Verrucaria hochstetteri, V. marmorea, } \\
\text { Xanthoris, V. nigrescens, V. rubrocincta } \\
\text { Xanthoria parietina } \\
\text { Dring }\end{array}$ & {$[6,8-14]$} \\
\hline $\begin{array}{c}\text { Silicate rocks: } \\
\text { basalt, } \\
\text { serpentinite, } \\
\text { gabbro, } \\
\text { dolerite (diabase), } \\
\text { granite, } \\
\text { sandstone }\end{array}$ & $\begin{array}{c}\text { Fuscidea cyathoides } \\
\text { Tephromela atra (Lecanora atra) } \\
\text { Ochrolechia parella, O. tartarea } \\
\text { Ophioparma ventosa } \\
\text { Pertusaria corallina }\end{array}$ & {$[7,15-18]$} \\
\hline $\begin{array}{c}\text { Other rocks: } \\
\text { copper sulphide-bearing rocks and } \\
\text { its weathering products }\end{array}$ & $\begin{array}{l}\text { Acarospora rugulosa* } \\
\text { Lecidea lacteal * } \\
\text { L. inops * }\end{array}$ & {$[19,20]$} \\
\hline
\end{tabular}

* Copper oxalate, moolooite was found together with calcium oxalates. ( ) -in parentheses are the old names of lichen species

In this paper, we describe calcium oxalates that were found for the first time in lichen thalli on surfaces of apatite-nepheline rocks of southeastern and southwestern titanite-apatite ore fields of the Khibiny peralkaline massif (Kola Peninsula, NW Russia). The main species involved in biofouling and 
bearing oxalate crystals are characterized. Morphogenetic patterns of calcium oxalates formation are discussed using the results of model experiments.

\section{Materials and Methods}

\subsection{Sample Materials and Acquisition}

Fragments of rocks with biofilms that contain crustose lichens were collected during the 2018 field season from the surface of apatite-nepheline ore blocks from the dumps of Khibiny peralkaline massif (Sample 1, Figure 1a) and at the "Rock Garden" of the Kola Science Centre (Sample 2, Figure 1b).

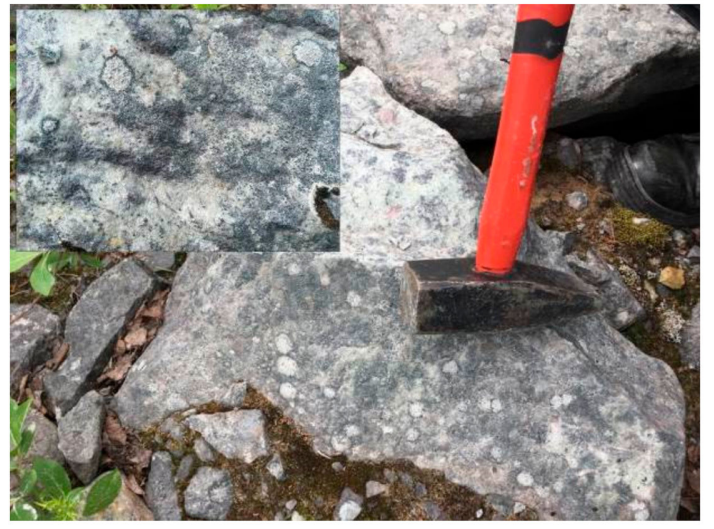

(a)

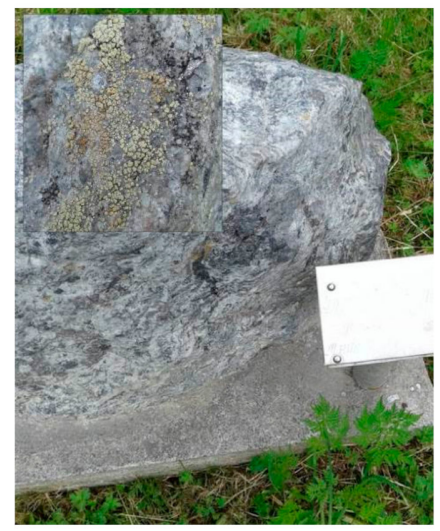

(b)

Figure 1. Apatite-nepheline ore blocks with biofilms that contain crustose lichens: Sample 1 is from the dumps of Khibiny peralkaline massif (a). Sample 2 is from the "Rock Garden" of the Kola Science Centre, 24a Fersmana str., Apatity, Murmansk region (b).

\subsection{Model Experiments}

Model experiments on the crystallization of calcium oxalates on the surface of apatite ore were carried out in a liquid nutrient medium with the participation of the microscopic fungus Aspergillus niger. For the experiment, a fragment of a fluorapatite-enriched rock without biofilm was taken from a stone block from the dumps of Khibiny peralkaline massif. Sample 1 containing biofilm was taken from the same stone block. A model experiment using fluorapatite rock from the "Rock Garden" was not carried out. Firstly, because this rock sample was close in its mineralogical and petrographic characteristics to rock sample from the dumps and, secondly, because its size was too small.

Aspergillus niger fungus was chosen because it is an active producer of organic acids, including oxalic acid [21,22]. For instance, Aspergillus niger (strain Ch4/07) was isolated from the damaged surface of Proconesos marble (Chersonesos, Crimea). Characterization of the strain was performed in the Research Center "Genomic technologies and cellular biology" of the All-Russian Research Institute of Agricultural Microbiology. The species identification of the strain was based on the sequence of the ITS region of rDNA (GenBank accession no. KF768341).

The experiments were carried out at room temperature $\left(20-25^{\circ} \mathrm{C}\right)$ in a liquid Capek-Dox medium (g/L: $\mathrm{NaNO}_{3}-2.0 ; \mathrm{KH}_{2} \mathrm{PO}_{4}-1.0 ; \mathrm{MgSO}_{4} \cdot 7 \mathrm{H}_{2} \mathrm{O}-0.5 ; \mathrm{KCl}-0.5 \mathrm{FeSO}_{4} \cdot 7 \mathrm{H}_{2} \mathrm{O}-0.01$; and glucose-30.0 g/L). The initial $\mathrm{pH}$ of the medium was 5.5. Fragments of apatite-nepheline rock (fragment sizes $\sim 5 \times 5 \mathrm{~mm}$ ) were placed on the bottom of a Petri dishes, and $15 \mathrm{~mL}$ of liquid Capek-Dox medium was added so that their surface was completely covered. Inoculation was performed with conidia of a microscopic fungus of a 10-day culture grown on a solid nutrient medium of Capek-Dox. The cultivation time ranged from 2 to 15 days, and the experiments were performed in triplicate with constant monitoring of the medium $\mathrm{pH}$. The $\mathrm{pH}$ values during the experiment were evaluated using $\mathrm{pH}$-meter Checker 1 (HI 98103). Initial pH value of the Capek-Dox medium was 5.5. 
Crystals formed on the surface of bedrock with fungal mycelium were investigated by complex methods.

\subsection{Optical Microscopy}

The method was used to check for any contamination of biofilms (bird's guano, pieces of concrete, dust, etc.), to study the petrographic features and mineral composition of bedrocks, and to identify microorganisms of the studied biofilms. Thin sections of the bedrock samples were studied under a petrographic microscope (Leica DM4500P) using polarized light. Lichen thalli and microscopic fungus cultures samples were examined using a MZ16 Leica stereo microscope and Leica DM300 LED microscope. The identification of lichens under the microscope was carried out on the basis of the laboratory of flora of the Polar Alpine Botanical Garden-Institute (PABGI), the Kola Science Centre (KSC) of the Russian Academy of Sciences (RAS) and the laboratory of terrestrial ecosystems of the Institute of North Industrial Ecology Problems (INEP), the Kola Science Centre (KSC) of the Russian Academy of Sciences (RAS). The following guidebooks and monographs were used [23,24]. The remaining samples not destroyed by the analyses were transferred to INEP, KPABG, and LECB collections-you can track the status and current location of the samples on the lichen page of CRIS IP Database [25]. Modern taxonomy of lichens is given by Indexfungorum.org [26], Mycobank.org [27], and Santesson's Checklist of Fennoscandian Lichen-forming and Lichenicolous Fungi [28].

Micromycetes from biofilms were identified after isolation to the nutrient media in accordance with guidebooks and monographs $[29,30]$. Modern taxonomy of microscopic fungi is given by Indexfungorum.org [26].

\subsection{X-Ray Powder Diffraction (XRD)}

This method was used to refine the mineral composition of the bedrock and to determine the phase composition of crystals in biofilms and in the model experiments products. The measurements were performed using a Rigaku "MiniFlex II" powder diffractometer (CuK $\alpha$ radiation, $\lambda=1.54178 \AA$; $30 \mathrm{kV} / 15 \mathrm{~mA}$; D-Tex Ultra detector). X-ray diffraction patterns were collected at room temperature in the range of $3-60^{\circ} 2 \theta$ with a step of $0.02^{\circ} 2 \theta$. Phase identification was carried out using the ICDD PDF-2 Database (release 2016).

\subsection{Scanning Electron Microscopy (SEM) and Energy-Dispersive X-Ray Spectroscopy (EDX)}

These methods were used to study the morphological features of calcium oxalate crystals found in biofilms and obtained during synthetic experiments. The refinement of the identification of calcium oxalates (monoclinic whewellite and tetrahonal weddellite) was also carried out via SEM images according to morphological features of the phases.

Measurements have been performed using the Desktop Scanning Electron Microscope TM3000 (Hitachi), which is equipped with OXFORD energy dispersive microanalysis attachment and secondary electron (Everhart-Thornley) detector based on the highly sensitive YAG crystal with the resolution of $0.1 \mathrm{Z}$ of the atomic number. The specimens were coated with carbon $(\sim 15 \mathrm{~nm})$. Magnification range varied from $100 \times$ to $1000 \times$.

\section{Results}

\subsection{Bedrock Characterization}

The results of the comprehensive study of samples 1 and 2 (thin sections and XRD) confirmed that the bedrock is mainly composed of fluorapatite and nepheline (Figures 2 and 3 (1)). According to EDX, Sr admixture is present in fluorapatite areas of rock (Figure 4a).

Fluorapatite forms small isometric grains $(<0.05 \mathrm{~mm})$ as well as tabular, short-columnar, and needle-shaped crystals (from 1 to $5 \mathrm{~mm}$ size along the $c$ axis), which often form chain and parallel-columnar aggregates (Figure 2a,b). Nepheline is represented by tabular crystals (up to $3 \mathrm{~mm}$ ) 
that often contain intergrowth of apatite. Alkaline pyroxene (aegirine), titanite, and titanomagnetite were found as the minor minerals.

Minerals are nonuniformly distributed. There are monomineral areas of the rock composed of fluorapatite or nepheline as well as areas composed of nearly equal grains of fluorapatite and nepheline wherein interstices are filled mainly with pyroxene grains. Titanite and titanomagnetite usually fill the interstices of idiomorphic fluorapatite and nepheline grains (Figure 2c,d).
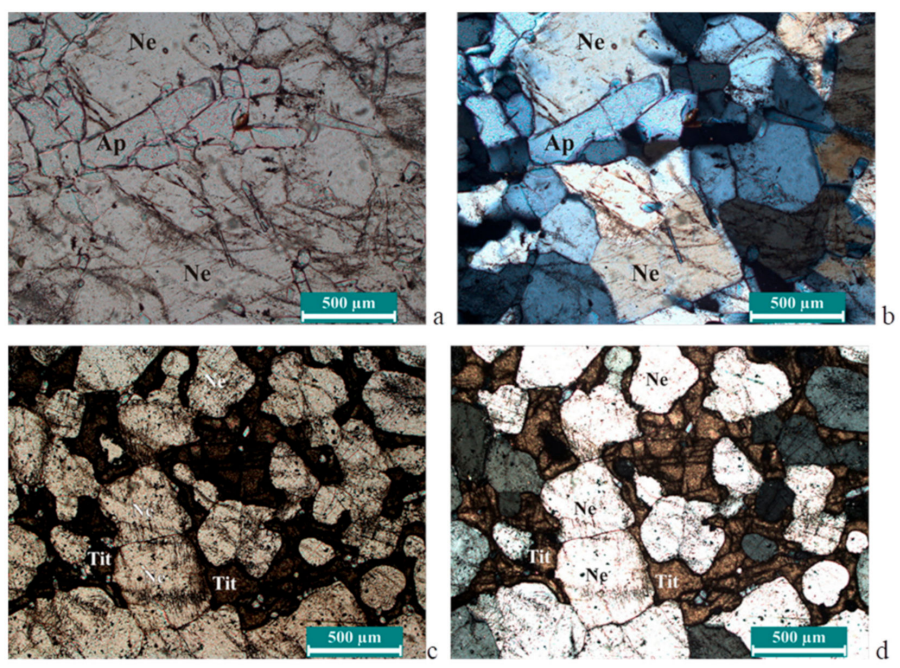

Figure 2. Light microscope images of the apatite-nepheline rock thin sections of Sample 1: PPL (a,c); XPL (b,d). Symbols: Ap-fluorapatite, $\mathrm{Ne}$-nepheline, Tit—-titanite.

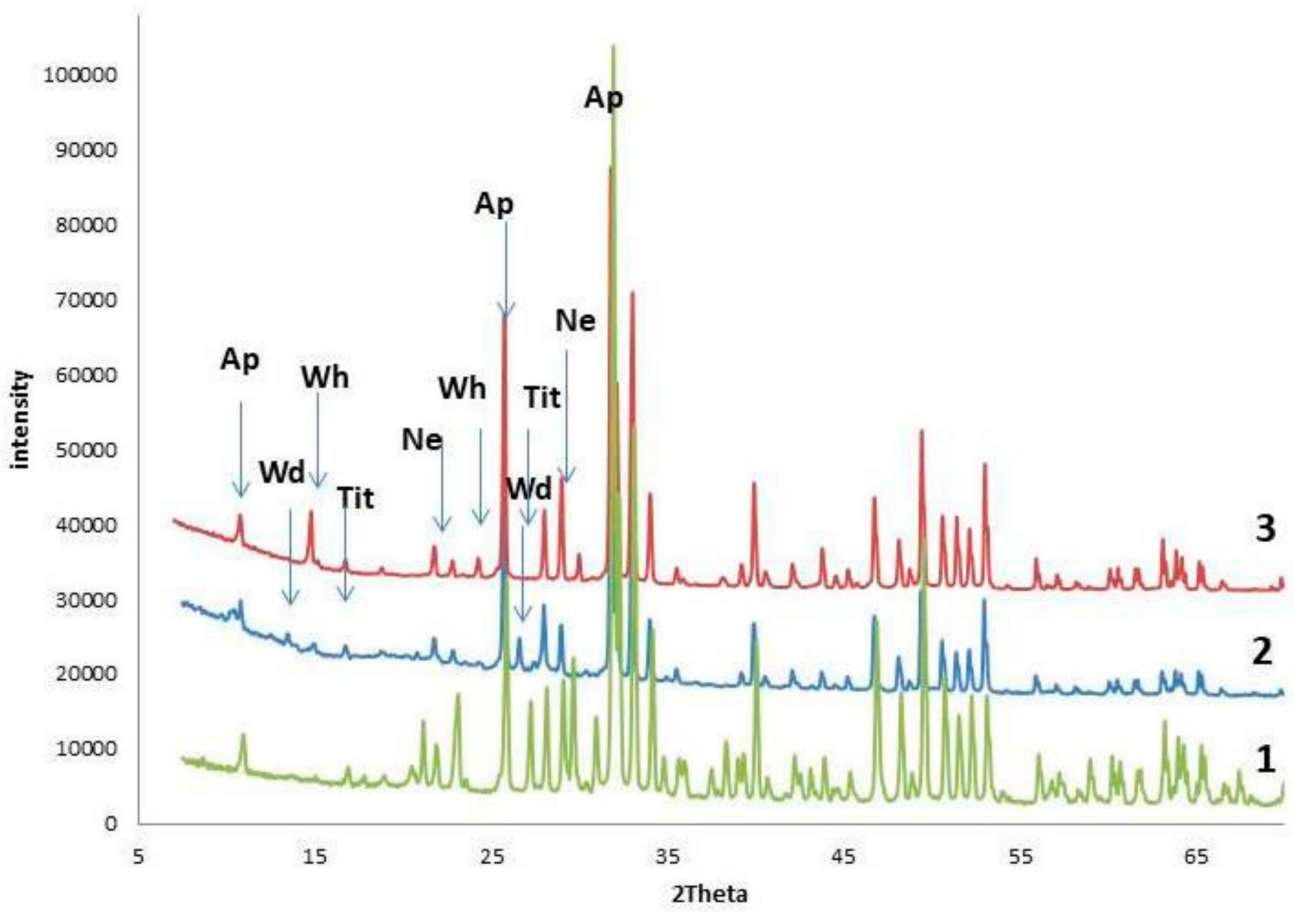

Figure 3. Powder X-ray diffraction patterns: fluorapatite-nepheline bedrock (fluorapatite, nepheline, and titanite) (1), mineral inclusions in the thallus of Farnoldia jurana on fluorapatite area of rock (2); and product of 5 days impact of Aspergillus niger on the fluorapatite area of rock (3). Symbols: Wd-weddellite, Wh-whewellite, Ap-fluorapatite, Ne-nepheline, Tit—-titanite. 

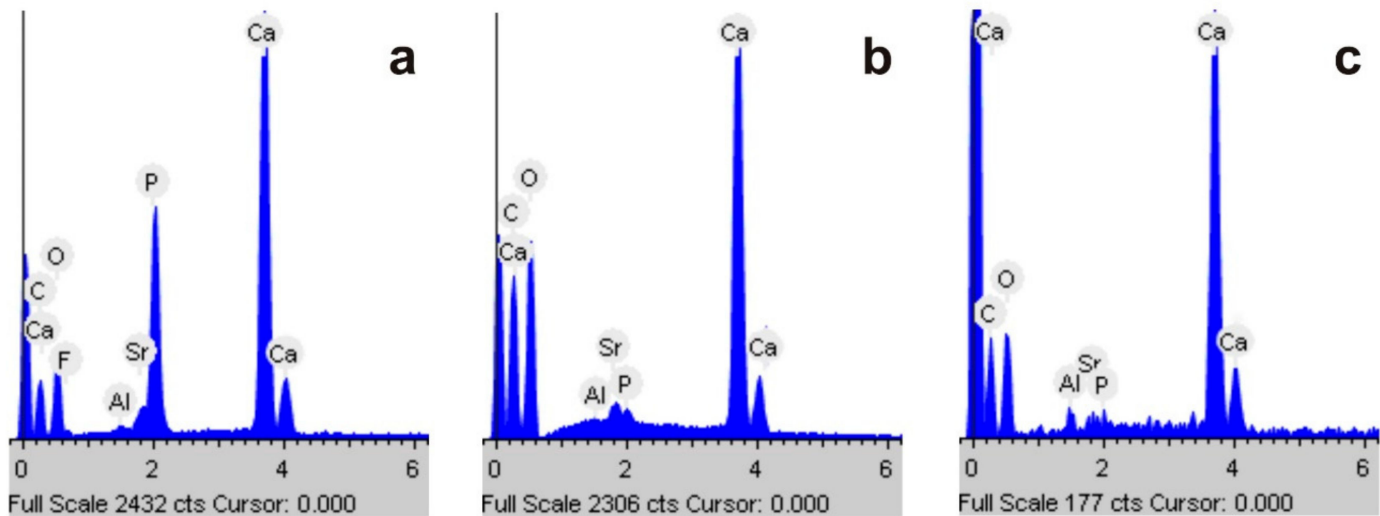

Figure 4. EDX spectra: fluorapatite bedrock, sample 2 (a); weddellite crystals formed in tallus of Lecanora polytropa, sample 2 (b); and biomimetic whewellite crystals (c).

\subsection{Species Composition of Biofilms}

Ten species of lichens and 10 species of micromycetes as well as Mycelia sterilia light-colored fungal isolates were found within the studied biofilms (Table 2). Among the detected micromycetes, species capable of producing oxalic acid were found, for instance, Penicillium lanosum, Pseudogymnoascus pannorum, Mortierella lignicola, and Trichoderma koningii [31-33].

Table 2. The species composition of lichens and fungi on apatite-nepheline rock.

\begin{tabular}{|c|c|c|c|}
\hline \multicolumn{2}{|c|}{ Sample 1} & \multicolumn{2}{|c|}{ Sample 2} \\
\hline Species of Lichens & $\begin{array}{c}\text { Species of } \\
\text { Micromycetes }\end{array}$ & Species of Lichens & $\begin{array}{c}\text { Species of } \\
\text { Micromycetes }\end{array}$ \\
\hline $\begin{array}{c}\text { Farnoldia jurana (Schaer.) } \\
\text { Hertel } \\
\text { Bellemerea alpina } \\
\text { (Sommerf.) Clauzade \& } \\
\text { Cl. Roux } \\
\text { Bellemerea subsorediza } \\
\text { (Lynge ex A.E. Dahl) R. } \\
\text { Sant. } \\
\text { Srereocaulon sp. } \\
\text { Stereocaulon nanodes Tuck. } \\
\text { Porpidia macrocarpa (DC.) } \\
\text { Hertel \& A.J. Schwab }\end{array}$ & $\begin{array}{c}\text { Alternaria alternata (Fr.) } \\
\text { Keissl. } \\
\text { Cladosporium herbarum } \\
\text { (Pers.) Link } \\
\text { Didymella glomerata } \\
\text { (Corda) Qian Chen \& L. } \\
\text { Cai } \\
\text { Mortierella lignicola (G.W. } \\
\text { Martin) W. Gams \& R. } \\
\text { Moreau } \\
\text { Oidiodendron griseum } \\
\text { Robak } \\
\text { Penicillium lanosum } \\
\text { Westling } \\
\text { Pseudogymnoascus } \\
\text { pannorum (Link) Minnis } \\
\text { \& D.L. Lindner } \\
\text { Scytalidium lignicola } \\
\text { Pesante } \\
\text { Trichoderma koningii } \\
\text { Oudem. } \\
\text { Mycelia sterilia }\end{array}$ & $\begin{array}{c}\text { Lecanora intricata (Ach.) } \\
\text { Ach. } \\
\text { Lecanora polytropa (Ehrh. } \\
\text { Ex Hoffm.) Rabenh. } \\
\text { Myriolecis dispersa (Pers.) } \\
\text { Śliwa et al. } \\
\text { Polysporina simplex } \\
\text { (Davies) Vezda }\end{array}$ & $\begin{array}{c}\text { Alternaria alternata (Fr.) } \\
\text { Keissl. } \\
\text { Cladosporium } \\
\text { cladosporioides (Fresen.) } \\
\text { G.A. de Vries } \\
\text { Cladosporium herbarum } \\
\text { (Pers.) Link } \\
\text { Scytalidium lignicola } \\
\text { Pesante } \\
\text { Mycelia sterilia }\end{array}$ \\
\hline
\end{tabular}

\subsection{Calcium Oxalates in Lichen Thalli on the Fluorapatite Areas of Rock}

According to the XRD, calcium oxalates found on the fluorapatite areas of rock in the thalli of the Farnoldia jurana, Lecanora polytropa, and Polysporina simplex lichens (Figure 5) are whewellite (calcium oxalate monohydrate) and weddellite (calcium oxalate dihydrate), which are presented in close proportions (Figure 3 (2)). Farnoldia jurana, Lecanora polytropa, and Polysporina simplex are 
widespread lichens in the northern hemisphere. The premier species inhabit hard limestones and some other carbonate substrates in damp situations, and the second is common on the wide range of siliceous rocks, while the last prefer siliceous or slightly carbonate rocks $[23,24]$. L. polytropa and P. simplex are well known from moderately anthropogenic-polluted territories; furthermore, L. polytropa is known as a copper accumulator [34].
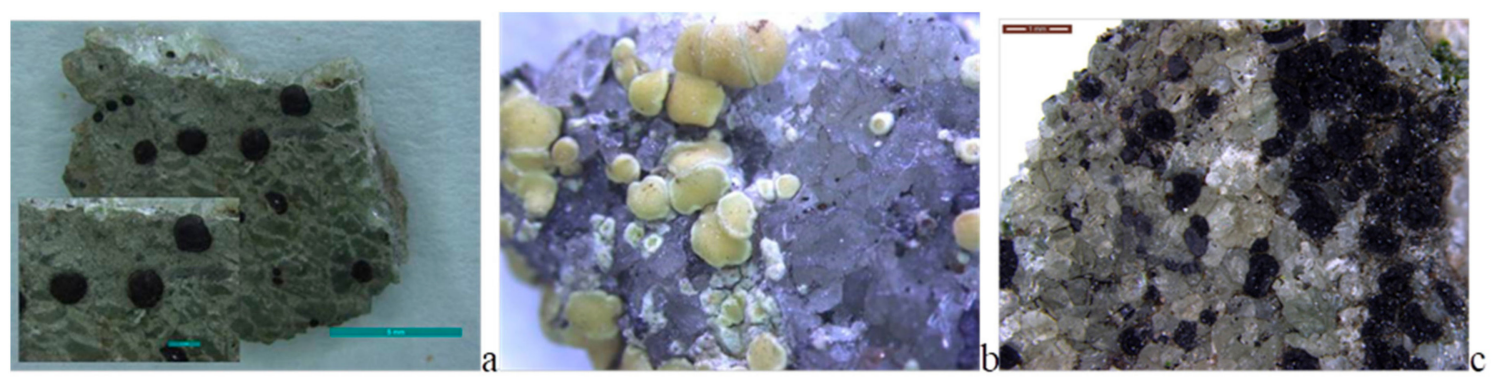

Figure 5. Species of lichens in which thalli calcium oxalates on the fluorapatite areas of rock were detected: Farnoldia jurana (Sample 1) (a), Lecanora polytropa (Sample 2) (b), and Polysporina simplex (Sample 2) (c).

SEM images clearly show that calcium oxalates are closely related to the hyphae of the fungal component of lichen (Figure 6). Weddellite is characterized by dipyramidal-prismatic and dipyramidal crystals; its maximal size is up to $25 \mu \mathrm{m}$. Numerous weddellite crystals are observed with traces of dissolution and cleavage. Whewellite is represented by fine-grained aggregates up to $5 \mu \mathrm{m}$ (Figure 6). 

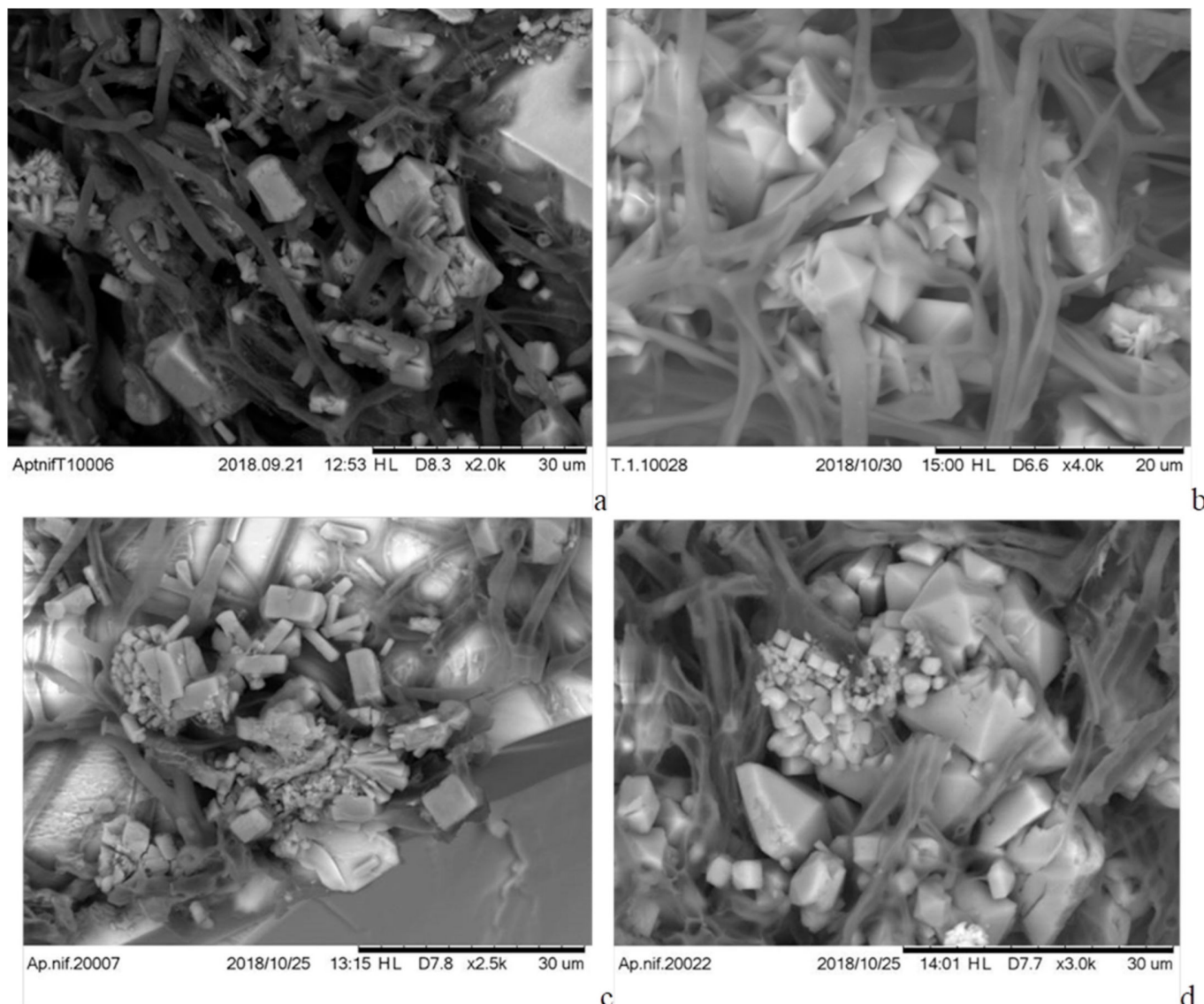

b
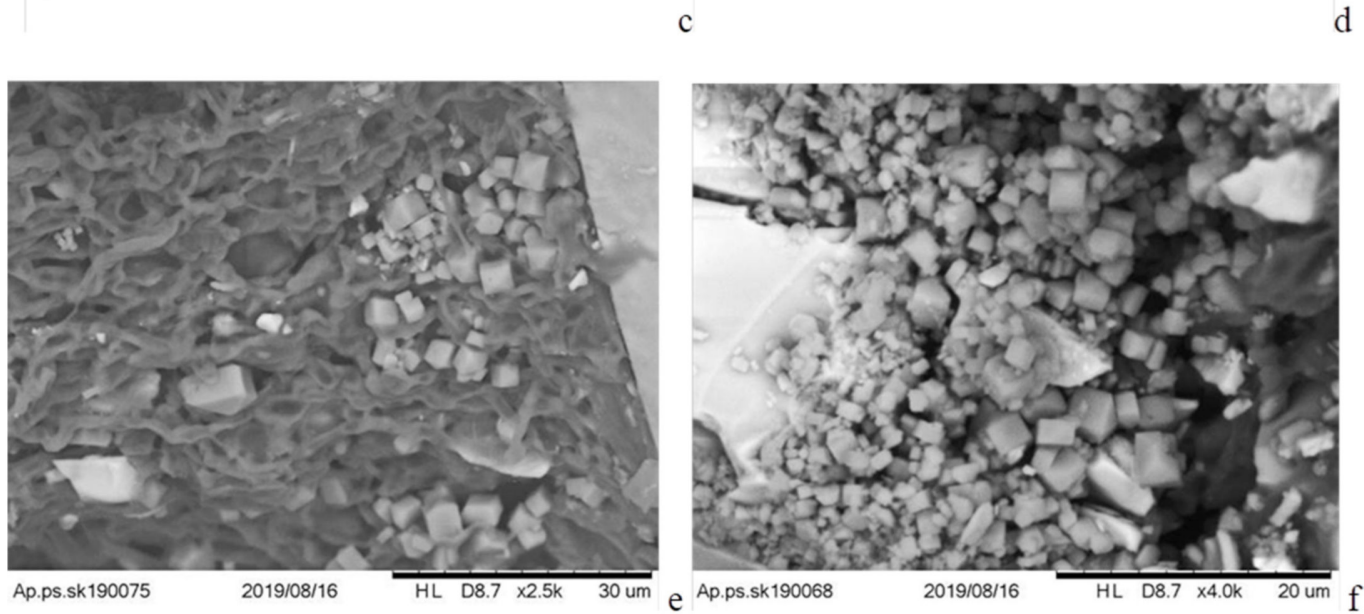

Figure 6. SEM images of calcium oxalates in Farnoldia jurana $(\mathbf{a}, \mathbf{b})$, Lecanora polytropa (c,d), and Polysporina simplex $(\mathbf{e}, \mathbf{f})$ lichens on the surfaces of fluorapatite areas of rock: Figure $6 \mathrm{a}, \mathrm{c}, \mathrm{e}$ presents the accumulation of small whewellite and weddellite crystals and large dipyramidal prismatic crystals are weddellite; Figure $6 \mathrm{~b}, \mathrm{~d}, \mathrm{f}$ presents weddellite crystals with various development of prism faces and fine-grained whewellite aggregates.

The EDX data indicate the presence of admixture ions $\left(\mathrm{Sr}^{2+}\right.$ and $\left.\mathrm{Al}^{3+}\right)$ in weddellite crystals found in the thallus of lichens on fluorapatite areas of rock (Figure $4 b$ ). In whewellite crystals, the same impurities are present in much smaller amounts. 
3.4. Calcium Oxalates Formed in the Experiment on Fluorapatite Bedrock under the Action of the Fungus Aspergillus Niger

Calcium oxalates that formed in all triplicates of the experiment on the surface of fluorapatite bedrock under the action of fungus Aspergillus niger, according to XRD and SEM, are represented by whewellite (Figure 3 (3) and Figure 7). According to EDX data, admixture ions in biomimetic whewellite crystals (as well as in biofilm whewellite crystals) are present in very small amounts. (Figure 4c). On the 5th day of the experiment, along with the intense oxalate crystallization, active dissolution of fluorapatite bedrock is observed according to SEM analysis (Figure 7a). Most of the whewellite crystals are characterized by multiple splitting and the formation of spherulite-like aggregates, which are absent for those oxalates found in thalli of lichens (Figure 6). The sizes of synthesized intergrowths (from 30 to $50 \mu \mathrm{m}$ ) are significantly larger than that of natural oxalates. On the 12th day of the experiment, the formation of small (from 15 to $30 \mu \mathrm{m}$ ) whewellite crystals of subsequent generations is observed (Figure $7 b$ ), i.e., crystallization of oxalates continues. The $\mathrm{pH}$ value decreased from 5.5 to 4.0 on the 5 th day of experiment and increased slightly to 4.5 at the end of the experiment that is well explained by features of acid production of the Aspergillus niger fungus [21,22].

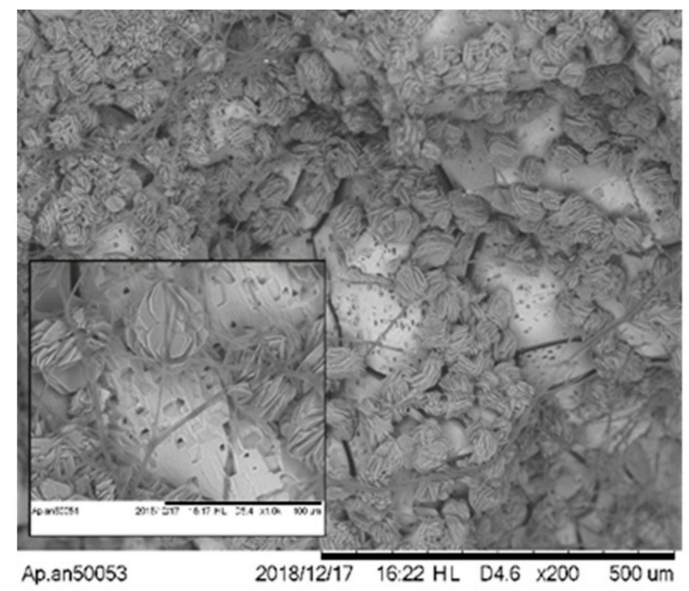

(a)

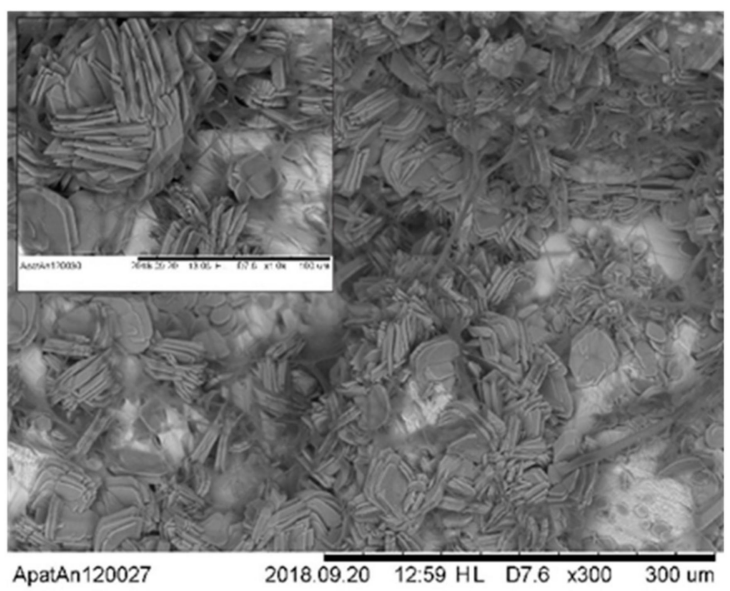

(b)

Figure 7. Calcium oxalates formed in the experiment on fluorapatite bedrock under the action of the Aspergillus niger fungus: after 5 days (a); after 12 days (b).

\section{Discussion}

The results of the current study indicate intense oxalate crystallization occurring on the surface of fluorapatite bedrock under the action of microorganisms (lichens and microscopic fungi). Calcium oxalates have been detected in the thalli of Farnoldia jurana, Lecanora polytropa, and Polysporina simplex lichens at contact with fluorapatite areas of rock (Figure 5, Table 2). These data indicate that the mycobiont of the mentioned lichen species is capable of secreting oxalic acid. While copper oxalate was previously found in the lichen Lecanora polytropa [34], no oxalic acid salts were previously encountered in the thallus of Farnoldia jurana and Polysporina simplex. The presence of Farnoldia jurana and Myriolecis dispersa species on apatite-nepheline ore is frequently due to the presence of concrete contaminants; however, no concrete admixtures have been detected on the particular sample. Among the detected micromycetes, other species capable of producing oxalic acid were found, for instance, Penicillium lanosum, Pseudogymnoascus pannorum, Mortierella lignicola, and Trichoderma koningii [31-33].

Phase composition and morphology of calcium oxalate crystals found in thalli of lichens on the surface of fluorapatite substrate are closely related to oxalate crystals formed in biofilms on the surface of carbonate rocks $[6,9,10,12,14,35,36]$. In all these cases, there are both calcium oxalate monohydrate and dihydrate (whewellite and weddellite) observed at the boundary of the rock and 
biofilm. Whewellite is present in the form of fine-grained aggregates, while weddellite is in the form of dipyramidal and dipyramidal-prismatic crystals (Figure 7). There are slight differences between the weddellite crystals morphology: weddelite crystals with significantly developed prism faces (in comparison with dipyramid faces) as well as numerous weddellite crystals with traces of a splitting are typical for oxalates developed on apatite rocks (Figure 6), and such forms are not found on surfaces of carbonate rocks.

It is known that phase composition of calcium oxalates and the morphology of their crystals are determined by the chemistry of the crystallization medium [37,38]. In the case of oxalates formed in biofilms, the chemical composition of the crystallization medium depends both on the elemental composition of the bedrock substrate and on the composition of the metabolic products secreted by microorganisms. The closeness of phase composition and morphology of the calcium oxalate crystals formed on apatite ore and carbonate rocks (marbles and limestones) suggests that the presence of $\mathrm{CO}_{3}{ }^{2-}$ and $\mathrm{PO}_{4}{ }^{3-}$ anions in the crystallization medium does not or almost does not affect the morphogenetic features of the calcium oxalate formation in the lichen thallus.

In both cases, formation of whewellite and weddellite (which is regarded as metastable in the field of whewellite) can be explained by the significant concentration of $\mathrm{Ca}^{2+}$ ions in the solution, which come mainly from the underlying fluorapatite rock, and by the presence of a number of inorganic and organic impurities $[37,39,40]$ that incorporate into the crystallization medium from the apatite substrate and, together with metabolic products of microorganisms, that present in biofilms. It can be assumed that $\mathrm{Sr}^{2+}$ and other admixture ions which predominantly incorporate into weddellite are among the impurities that contribute to its stabilization on the surface of the apatite-nepheline rock. These impurities leached from the apatite rock (Figure $4 \mathrm{a}$ ) and substitute $\mathrm{Ca}^{2+}$ ions in the weddellite structure [41]. It can be assumed that, on the surface of carbonate rocks, weddellite stabilization can be facilitated by $\mathrm{Mg}^{2+}$ ions [37], which are almost always present in calcite as an isomorphic impurity [42]. Moreover, the stabilization of weddellite can be also facilitated by the presence of citric acid in the crystallization medium [37], which could be released by micromycetes that live on the surface of bedrock. Citric acid could be produced on the apatite substrate by Penicillium lanosum, Pseudogymnoascus pannorum, and Trichoderma koningii micromycetes (Table 2) [32,43].

It is known that, on the calcite marble under the influence of the Aspergillus niger fungus, both whewellite and weddellite are formed under the experimental conditions $[22,35,44]$. According to our experiment, only calcium oxalate monohydrate, whewellite, was formed on the apatite rock under the action of the same fungus (Figure 7). This difference can be explained by the significantly lower solubility of fluorapatite under the action of fungal metabolism products compared to calcite marble, which leads to a decrease in the ratio of $\mathrm{Ca}^{2+}$ and oxalate ions in the crystallization medium and, accordingly, to a shift into the crystallization region, in which weddellite is not stable.

Formation of weddellite together with whewellite in biofilms with a predominance of crustaceous lichens on the surface of fluorapatite substrate suggests that the complex microbial composition of the biofilm is one of the main factors leading to stabilization of calcium oxalate dihydrate. Unfortunately, the metabolic activity of lichens has not been sufficiently studied to date; that does not allow us to identify their metabolism products which play crucial roles in the oxalate formation in lichen-dominant biofilms.

Various developments of the prism faces of weddellite formed in biofilms on the surface of apatite substrate are well explained by the preferential adsorption of admixture components on these faces [22,40]. Variations in the content and, probably, in the composition of impurities adsorbed on the prism faces lead to various degrees of inhibition of its growth and development. The inhibition process is the most intensively developed on the fluorapatite bedrock, where weddellite crystals with the significantly more developed prism faces than the dipyramid faces were found. It should be noted that the crystals of similar morphology are not observed on carbonate rocks. It is likely that such stronger (than on marble) adsorption interaction of impurities with weddellite crystals during their growth leads to the appearance of numerous weddellite crystals on the surface of the fluorapatite bedrock with traces of splitting that are not found on carbonate rocks. 


\section{Conclusions}

The present work contributes to the essential questions on calcium oxalate formation under the influence of lithobiont community organisms. Detection of calcium oxalates in lichens thalli on the surface of apatite-nepheline ore demonstrates that oxalate crystallization under the action of rock-inhabiting organisms can take place on the surface of different Ca-bearing rocks and minerals. Therefore, the searches for oxalate mineralization in biofilms on various rock substrates should be continued.

It was shown that, among the complex of factors determining the morphogenetic patterns of biogenic oxalate formation, one of the main roles belong to the metabolic activity of the lithobiont community organisms, which differs significantly from the activity of its individuals $[44,45]$. This result indicates a significant effect of microbial physiological processes on the chemistry of the crystallization medium in biofilms on the surface of various rocks and is well explained by selectively accumulation of elements from the environment by microorganisms during biofouling [31,46].

Author Contributions: Conceptualization, O.V.F.-K., G.Y.I., and D.Y.V.; investigation, M.S.Z., A.R.I., and E.I.P.; methodology, O.V.F.-K., M.S.Z., A.R.I., and A.O.K.; visualization, M.S.Z., A.R.I., and E.I.P.; writing-original draft, O.V.F.-K., M.S.Z., A.R.I., and A.O.K.; writing—review and editing, O.V.F.-K., G.Y.I., and D.Y.V.

Funding: This research was funded by the Russian Science Foundation (grant 19-17-00141 to O.V.F.-K., M.S.Z., A.R.I., and D.Y.V).

Acknowledgments: The authors would like to thank Melechin A.V, Gimelbrant D.E., and Sazanova K.V. for consultations provided during the preparation of the article. The laboratory researches were carried out in the Research Resource Centers of Saint Petersburg State University, the SEM investigations were carried out in the "Resource Center Microscopy and Microanalysis (RCMM)", and the XRD measurements were carried out in the X-ray Diffraction Centre.

Conflicts of Interest: The authors declare no conflict of interest.

\section{References}

1. Sayer, J.A.; Gadd, J.M. Solubilization and transformation of insoluble inorganic metal compounds to insoluble metal oxalates by Aspergillus niger. Mycol. Res. 1997, 6, 653-661. [CrossRef]

2. Sayer, J.A.; Kierans, M.; Gadd, J.M. Solubilisation of some naturally occurring metal-bearing minerals, limescale and lead phosphate by Aspergillus niger. Fems Microbiol. Lett. 1997, 154, 29-35. [CrossRef] [PubMed]

3. Burford, E.P.; Kierans, M.; Gadd, J.M. Geomycology: Fingi in mineral substrata. Mycologist 2003, 1717, 98-107. [CrossRef]

4. Gadd, G.M.; Bahri-Esfahani, J.; Li, Q.W.; Rhee, Y.J.; Wei, Z.; Fomina, M.; Liang, X.J. Oxalate production by fungi: Significance in geomycology, biodeterioration and bioremediation. Fungal Biol. Rev. 2014, 28, 36-55. [CrossRef]

5. Ferrier, J.; Yang, Y.; Cseteny, L.; Gadd, G.M. Colonization, penetration and transformation of manganese oxide nodules by Aspergillus niger. Env. Microbiol. 2019, 2121, 1821-1832. [CrossRef] [PubMed]

6. Syers, J.K.; Birnie, A.C.; Mitchell, B.B. The calcium oxalate content of some lichens growing on limestone. Lichenologist 1967, 3, 409-414. [CrossRef]

7. Wilson, M.J.; Jones, D.; McHardy, W.J. The weathering of serpentinite by Lecanora atra. Lichenologist 1981, 13, 167-176. [CrossRef]

8. Marques, J.; Gonçalves, J.; Oliveira, C.; Favero-Longo, S.E.; Paz-Bermúdez, G.; Almeida, R.; Prieto, B. On the dual nature of lichen-induced rock surface weathering in contrasting micro-environments. Ecology 2016, 9797, 2844-2857. [CrossRef]

9. Gehrmann, C.K.; Krumbein, W.E. Interaction between epilithic and endolithic lichens and carbonate rocks. In III International Symposium on the Conservation of Monuments in the Mediterranean Basin; ICCROM: Rome, Italy, 1994; pp. 311-316.

10. Ascaro, C.; Galvan, J.; Rodgriguez-Pascual, C. The weathering of calcareous rocks by lichens. Pedobiologia $1982,24,219-229$.

11. Bungartz, F.; Garvie, L.A.J.; Nash, T.H. Anatomy of the endolithic Sonoran Desert lichen Verrucaria rubrocincta Breuss: Implications for biodeterioration and biomineralization. Lichenologist 2004, 36, 55-73. [CrossRef] 
12. Ríos de los, A.; Cámara, B.; Cura del, M.Á.G.; Rico, V.J.; Galván, V.; Ascaso, C. Deteriorating effects of lichen and microbial colonization of carbonate building rocks in the Romanesque churches of Segovia (Spain). Sci. Total Env. 2009, 407, 1123-1134.

13. Souza-Egipsy, V.; Wierzchos, J.; Carcia-Ramos, J.V.; Ascaro, C. Chemical and ultrastructural features of the lichen-volcanic sedimentary rock interface in a semiarid region (Almeria, Spain). Lichenologist 2002, 34, 155-167. [CrossRef]

14. Rusakov, A.V.; Frank-Kamenetskaya, O.V.; Zelenskaya, M.S.; Vlasov, D.Y.; Gimelbrant, D.E.; Knauf, I.V.; Plotkina, Y.V. Calcium oxalates in bio-films on surface of the chersonesus archaeological limestone monuments (Crimea). Zap. Rmo (Proc. Russ. Mineral. Soc. Russ.) 2010, 5, 96-104.

15. Jones, D.; Wilson, M.J.; Tait, J.M. Weathering of a basalt by Pertusaria corallina. Lichenologist 1980, 12, $277-289$. [CrossRef]

16. Adamo, P.; Marchetiello, A.; Violante, P. The weathering of mafic rocks by lichens. Lichenologist 1993, 25, 285-297. [CrossRef]

17. Prieto, B.; Silva, B.; Rivas, T.; Wierzchos, J.; Ascaso, C. Mineralogical transformation and neoformation in granite caused by the lichens Tephromela atra and Ochrolechia parella. Int. Biodeterior. Biodegrad. 1997, 40, 191-199. [CrossRef]

18. Bjelland, T.; Smbo, L.; Thorseth, I.H. The occurrence of biomineralization products in four lichen species growing on sandstone in western Norway. Lichenologist 2002, 34, 429-440. [CrossRef]

19. Chisholm, J.E.; Jones, G.C.; Purvis, O.W. Hydrated copper oxalate, moolooite in lichens. Mineral. Mag. 1987, 51, 766-803. [CrossRef]

20. Purvis, O.W. The occurrence of copper oxalates in lichens crowing on copper sulphide-bearing rocks in Scandinavia. Lichenologist 1984, 16, 197-204. [CrossRef]

21. Barinova, K.V.; Vlasov, D.Y.; Schiparev, S.M.; Zelenskaya, M.S.; Rusakov, A.V.; Frank-Kamenetskaya, O.V. Organic acids o microfungi isolated from the rock substrates. Mikol. Fitopatol. 2010, 44, 137-142.

22. Sturm, E.V.; Frank-Kamenetskaya, O.V.; Vlasov, D.Y.; Zelenskaya, M.S.; Sazanova, K.V.; Rusakov, A.V.; Kniep, R. Crystallization of calcium oxalate hydrates by interaction of calcite marble with fungus Aspergillus niger. Am. Miner. 2015, 100, 2559-2565. [CrossRef]

23. Smith, C.W.; Aptroot, A.; Coppins, B.J.; Fletcher, A.; Gilbert, O.L.; James, P.W.; Wolseley, P.A. The Lichen Flora of Great Britain and Ireland; British Lichen Society: London, UK, 2009; p. 1046.

24. Wirth, V.; Hauck, M.; Schultz, M. Die Flechten Deutschlands; Band 1; 2013; 672 pp.; Band 2; Eugen Ulmer KG: Stuttgart, Germany, 2013; p. 4.

25. Available online: http://kpabg.ru/l (accessed on 13 September 2019).

26. Available online: http://www.indexfungorum.org (accessed on 13 September 2019).

27. Available online: http://www.mycobank.org (accessed on 13 September 2019).

28. Available online: http://130.238.83.220/santesson/home.php (accessed on 13 September 2019).

29. Ellis, M.B. Dematiaceous Hyphomycetes; Commonwealth Mycological Institute: Kew, Surrey, UK, 1971; pp. 1-608.

30. Satton, D.; Fothergill, A.; Rinaldi, M. Identifier of Pathogenic and Conditionally Pathogenic Fungi; Mir: Moscow, Russia, 2001; pp. 1-486. (In Russian)

31. Sazanova, K.V.; Vlasov, D.Y.; Shavarda, A.L.; Zelenskaya, M.S.; Kuznetsova, O.A. Metabolomic approach to studying lithobiontic communities. Biosphere 2016, 8, 291-300. (In Russian)

32. Magnuson, J.K. Organic acid production by filamentous fungi. In Advances in Fungal Biotechnology for Industry, Agriculture, and Medicine; Magnuson, J.K., Lasure, L.L., Eds.; Springer: Boston, MA, USA, 2004; pp. 307-340.

33. Osorio, N.W.; Habte, M. Soil phosphate desorption induced by a phosphate-solubilizing fungus. Commun. Soil Sci. Plant Anal. 2014, 45, 451-460. [CrossRef]

34. Purvis, O.W.; Pawlik-Skowronska, B.; Cressey, G.; Jones, G.C.; Kearsley, A.; Spratt, J. Mineral phase and element composition of the copper hyperaccumularor lichen Lecanora polytropa. Mineral. Mag. 2008, 72, 607-616. [CrossRef]

35. Frank-Kamenetskaya, O.V.; Vlasov, D.Y.; Shilova, O.A. Biogenic Crystals Genesis on a Carbonate Rock Monument Surface: The Main Factors and Mechanisms, the Development of Nanotechnological Ways of Inhibition. In Minerals as Advanced Materials II.; Krivovichev, S., Ed.; Springer: Berlin/Heidelberg, Germany, 2012; pp. 401-413. 
36. Edwards, H.G.M.; Farwell, D.W.; Seaward, M.R.D. FT-Raman spectroscopy of Dirina massiliensis f.sorediata encrustations growing on diverse substrata. Lichenologist 1997, 29, 83-90. [CrossRef]

37. Kuz'mina, M.A.; Rusakov, A.V.; Frank-Kamenetskaya, O.V.; Vlasov, D.Y. The influence of inorganic and organic components of biofilm with microscopic fungi on the phase composition and morphology of crystallizing calcium oxalates. Crystallogr. Rep. 2019, 64, 161-167. [CrossRef]

38. Wei, S.; Cui, H.; Jiang, Z.; Liu, H.; He, H.; Fang, N. Biomineralization processes of calcite induced by bacteria isolated from marine sediments. Braz. J. Microbiol. 2015, 46, 455-464. [CrossRef]

39. Izatulina, A.R.; Gurzhiy, V.V.; Frank-Kamenetskaya, O.V. Weddellite from renal stones: Structure refinement and dependence of crystal chemical features on $\mathrm{H}_{2} \mathrm{O}$ content. Am. Mineral. 2014, 99, 2-7. [CrossRef]

40. Thomas, A.; Rosseeva, E.; Hochrein, O.; Carrillo-Cabrera, W.; Simon, P.; Duchstein, P.; Zahn, D.; Kniep, R. Mimicking the growth of a pathogenic biomineral: Shape development and structures of calcium oxalate dehydrate in the presence of polyacrylic acid. Chem.-A Eur. J. 2012, 18, 4000-4009. [CrossRef]

41. Frank-Kamenetskaya, O.V.; Izatulina, A.R.; Gurzhiy, V.V.; Zelenskaya, M.S.; Rusakov, A.V.; Kuz'mina, M.A. Ion substitutions and nonstoichiometry of oxalic acid salts formedwith participation of the litobiont microbial community. In Proceedings of the XIX International Meeting on Crystal Chemistry, X-Ray Diffraction and Spectroscopy of Minerals, Apatity, Russia, 2-5 July 2019; p. 185.

42. Loste, E.; Wilson, R.M.; Seshadri, R.; Meldrum, F.C. The role of magnesium in stabilizing amorphous calcium carbonate and controlling calcite morphologies. J. Cryst. Growth 2003, 254, 206-218. [CrossRef]

43. Sazanova, K.V.; Vlasov, D.Y.; Osmolovskay, N.G.; Schiparev, S.M.; Rusakov, A.V. Significance and regulation of acids production by rock-inhabited fungi. In Biogenic-Abiogenic Interactions in Natural and Anthropogenic Systems; Frank-Kamenetskaya, O.V., Panova, E.G., Vlasov, D.Y., Eds.; Springer: Berlin, Germany, 2016; pp. 379-392.

44. Rusakov, A.V.; Vlasov, A.D.; Zelenskaya, M.S.; Frank-Kamenetskaya, O.V.; Vlasov, D.Y. The crystallization of calcium oxalate hydrates formed by interaction between microorganisms and minerals. In Biogenic-Abiogenic Interactions in Natural and Anthropogenic Systems; Frank-Kamenetskaya, O.V., Panova, E.G., Vlasov, D.Y., Eds.; Springer: Berlin, Germany, 2016; pp. 357-377.

45. Sazanova, K.V.; Frank-Kamenetskaya, O.V.; Vlasov, D.Y.; Zelenskaya, M.S.; Vlasov, A.D.; Rusakov, A.V.; Petrova, M. Crystallization of calcium carbonates and oxalates on marble surface induced by metabolism of bacteria and bacterial-fungal associations. Cryst. Growth Des. 2019, in press.

46. Frank-Kamenetskaya, O.V.; Vlasov, D.Y.; Rytikova, V.V. (Eds.) The Effect of the Environment on Saint Petersburg's Cultural Heritage: Results of Monitoring the Historical Necropolis Monuments; Springer: Berlin, Germany, 2019; p. 188.

(C) 2019 by the authors. Licensee MDPI, Basel, Switzerland. This article is an open access article distributed under the terms and conditions of the Creative Commons Attribution (CC BY) license (http://creativecommons.org/licenses/by/4.0/). 